\title{
Cross-Sectional Study on Calf Health and Management Problems on Small Scale Dairy Farms of Sidama and Gedio Zones, Southern Ethiopia
}

Keywords: Bacterial isolation; Calf health and management problems; Gedio and Sidama Zones; Helminths identification; Small scale dairy farms

\begin{abstract}
A Cross-sectional study was conducted from October, 2010 to December, 2013 to assess the calf health and management problems and the associated risk factors in small scale dairy farms of Sidama and Gedio Zones. The study comprises 61 urbans, 46 peri-urban and 54 rura farms, from which 61 (37.7\%) are intensive, 47 (29.0\%) semi intensive and 54 (33.3) extensive farms. Data with regard to birth history, colostrum feeding management, vaccination practices and previous disease history of selected calves were collected with semi structured questionnaire and observational assessment; and microbiological identification and Flotation and Sedimentation techniques were part of the study methodology. Results indicate among the risk factors considered for analysis, only sex of farm owner, herd size and breed of calves were found to be significant with health problems of calves $(P<0.05)$. Birth condition of $16.28(n=14)$ calves were assisted, out of which 13 (15.12\%), were attended by non-professionals and $1(1.16 \%)$ of the cases were attended by professional veterinary practitioners. $50.0 \%$ delivery problem was both maternal and calf caused, oversized fetus and delivery impotency were mentioned by farmers as a potential cause for dystocia. Majority of the respondent $(92.6 \%)$ replied colostrum feeding and $7.4 \%$ not fed colostrum; general calf morbidity of $30.2 \% \quad(n=159)$, with zonal prevalence of Sidama zone $(29.3 \%)$, Gedio zone (35.0\%). High Prevalence of calf morbidity was seen in farms located in urban area $12.6 \%$ followed by rural farms $9.3 \%$ and urban farms $8.2 \%$. Septicemia and Diarrhea 21 (43.7\%) was found to be the most frequently observed disease syndrome followed by Internal parasite $15(31.2 \%)$, external parasite 8 (16.7\%), Coccidiosis $1(2.08 \%)$, Hemoparasite 1 (2.08\%) and mixed infection 2 (4.2\%). 50.9\% vaccinated their calves at least for one type of vaccine. The major internal parasites identified by floatation and sedimentation techniques were Strongyle spp. (32\%), emeria (16\%), neoasacris vitulorum (12.0\%), mixed parasite strongyle spp. and eimeria (10\%) and neoascaris vitulorum and Strongyle spp. (8\%). From the isolated bacteria, E. coli $(53.3 \%)$ was the higher prevalent and followed by proteus (10\%), Citrobacter (8.3\%), E. coli and Klebsiella mixed (8.3\%). In conclusion, this research revealed that the proportion of calf morbidity that caused by bacteria was higher than internal and external parasites caused calf morbidity, E. coli and Strongyle spp. were the dominant bacteria and interna parasites respectively in the study dairy farms; high calf morbidity in rural than urban areas and the majority respondents had an awareness of colostrums effect on their calves.
\end{abstract}

\section{Introduction}

The dairy industry is a large and dynamic segment of the agricultural economy of many nations and the major suppliers of milk and milk products to the urban and peri-urban consumers [1,2]. Peri-urban and urban dairies are intensive production systems, which keep high grade cows and have improved management practices but this is usually associated with increase susceptibility to disease, poor
Journal of

Veterinary Science \& Medicine

\author{
Yibrah Tekle $^{1^{*}}$ and Tsega Berihe ${ }^{2}$ \\ ${ }^{I}$ Department of Animal and Range Science, Dilla University, Ethiopia \\ ${ }^{2}$ Southern Agricultural Research Institute, Ethiopia \\ *Address for Correspondence \\ Yibrah Tekle, Department of Animal and Range Science, Dilla Uni- \\ versity, College of Agriculture and Natural Resource Science, Dilla, \\ Ethiopia, E-mail: goytomtekle@gmail.com \\ Submission: 07 March 2017 \\ Accepted: 15 April 2017 \\ Published: 25 April 2017 \\ Copyright: $\odot 2017$ Yibrah T. This is an open access article distributed \\ under the Creative Commons Attribution License, which permits \\ unrestricted use, distribution, and reproduction in any medium, provided \\ the original work is properly cited.
}

survival rate and poor reproductive performance [3-6].

Farms in young stock, a good nutritional strategy optimize rumen development and growth while minimizing stress and disease. Livestock housing and surrounding environment of dairy farm greatly affects health and productivity. A relationship between housing and health during the rearing period has been described by several authors. Following Hygienic conditions and Cleanliness of the barn influences calf health, as calves housed in unclean barns are at higher risk of disease than calves housed in clean barns [7-9].

Colostrum contains a high level of immunoglobulin's and other nutrients important for lamb health and gives immunity against a variety of infectious agents. The poor immune system and lack of previous exposure to infection make new born calves susceptible to infectious diseases and poor management [10-12]. Gastrointestinal helminthes are important pathogens which affect young livestock in many tropical and subtropical environments $[9,13,14]$. Treatment with anthelminthics administered 2-4 times a year, depending on climate and management practices, has been recommended for helminth control $[13,15]$. Diarrhea is one of the most important constraints in food animal production [16]. Its prevalence appears to be management related especially when calves are housed in unhygienic conditions [8,9].

According to ILCA [3] calf morbidity and mortality were ranked next to mastitis as the second biggest problem for dairy production in Ethiopia. Good calf rearing is important as it ensures availability of good future replacement stock. Most farmers do not have enough knowledge on importance of colostrum and proper calf-feeding regimes which provides disease resistance to calves. Apart from that, farmers aim to optimize income by selling more milk and calves are, therefore, underfed and unhygienic condition. This is more serious in male calves; however, studies conducted on calf management and health problems in both pre-weaning and post weaning stages. Therefore, the objectives of this study were to evaluate the existing calf health and management problems, to isolate bacteria and identify helminthes that caused health problem to calves in the study areas and to assess the level of farmers' knowledge on the calf health and management practices. 
Citation: Yibrah T, Tsega B. Cross-Sectional Study on Calf Health and Management Problems on Small Scale Dairy Farms of Sidama and Gedio Zones, Southern Ethiopia. J Veter Sci Med. 2017;5(1): 5.

ISSN: $2325-4645$

\section{Material and Methods}

\section{Study area}

According to the Sidama Zone Corporation Development, Sidama Zone is Northeast of Lake Abaya and Southeast of Lake Awasa. The Sidama live between Awasa town in the north and Dilla town in the south, spread out in a cone-shaped area of the middle of southern Ethiopia. Sidama is generally a fertile area, varying from flat land (warm to hot) to high land (warm to cold).

Sidama has geographic coordinates of latitude, North: $5^{\prime} 45^{\prime \prime}$ and $6^{\prime} 45^{\prime \prime}$ and longitude, East, $38^{\prime}$ and $39^{\prime}$. It has a total area of $10,000 \mathrm{~km}^{2}$, of which $97.71 \%$ is land and $2.29 \%$ is covered by water. Hawassa Lake and Logita falls are water bodies that attract tourists. Of the land, $48.70 \%$ is cultivated, $2.29 \%$ is forested, $5.04 \%$ is shrub and bush land, $17.47 \%$ is grazing land, $18.02 \%$ is uncultivated, $6.38 \%$ is unproductive and $2.10 \%$ is has other uses. Some of the cultivated lands are in undulating escarpment and create difficulties for the farmers in the area. Sidama have a variety of climatic conditions. Warm conditions cover $54 \%$ of the area. Locally known as Gamoojje or Woinadega, this is a temperate zone ranging from an elevation of $1500 \mathrm{~m}$ to $2500 \mathrm{~m}$ above sea level. The mean annual rainfall of the area varies between $1200 \mathrm{~mm}$ and $1599 \mathrm{~mm}$, with $15^{\circ} \mathrm{C}$ to $19.9^{\circ} \mathrm{C}$ average annual temperature. A hot climatic zone, Kolla, covers $30 \%$ of the total area. Its elevation ranges from $500 \mathrm{~m}$ to $1500 \mathrm{~m}$ above sea level. It has a mean annual rainfall of $400 \mathrm{~mm}$ to $799 \mathrm{~mm}$, and the mean annual temperature ranges from $20^{\circ} \mathrm{C}$ to $24.9^{\circ} \mathrm{C}$. Cool climatic conditions known as Aliicho or Dega exist in the mountainous highlands. This covers $16 \%$ of the total area with an elevation between $2500 \mathrm{~m}$ and $3500 \mathrm{~m}$ above sea level. This part gets the highest amount of rainfall, ranging from $1600 \mathrm{~mm}$ to $1999 \mathrm{~mm}$. It has a mean annual temperature of $15{ }^{\circ} \mathrm{C}$ to $19.9^{\circ} \mathrm{C}$. Zone has 19 districts and Cattle numbers are good indicator of wealth, and gives chief popularity for the farmer who owns more cattle.

Gedeo Zone is located in $369 \mathrm{~km}$ from Addis Ababa to southeon Addis Ababa-Moyale international road and $90 \mathrm{~km}$ from Hawassa (capital city of the region) in South Nation Nationality and People Regional State (SNNPRS). On the basis of the current border delineation, the land area of the region is estimated at 1347.04 square kilometers. Geographically, the Zone is located North of Equator from $5053^{\prime} \mathrm{N}$ to $6027^{\prime} \mathrm{N}$ Latitude and from $3808^{\prime}$ ' to 38030 ' East, Longitude. The altitude ranges from 1500 to $3000 \mathrm{~m}$.

The zone has sub-humid tropical climate receives mean annual rainfall 1500 with range of 1200 and $1800 \mathrm{~mm}$. The rainfall pattern is bimodal, with short rain season between March and May accounting for $30 \%$ of total rain fall and long rain season between July and October accounting for more than $60 \%$ of total rainfall. The mean monthly temperature is $21.5^{\circ} \mathrm{C}$ with mean monthly maximum and minimum temperature of $25{ }^{\circ} \mathrm{C}$ and $18{ }^{\circ} \mathrm{C}$, respectively. The Zone experiences three distinct agro ecologic Zone Namely 'Dega' (30\%), 'Woyina Dega' (67\%) and 'Kefil-Kola' (3\%). Gedio zone has 7 districts and located altitude of the Zone ranges from 1268 meters above sea level in the vicinity of Lake Abaya to an elevation of 2993 meters at Haro Wolabu Pond.

Study areas may be shown in a small table indicating altitude, temperature and rain fall only among all regions of country. No need of running matter.

\section{Study animals}

The representative farms from each study areas were selected depending on the availability of dairy farms. To select the representative farms discussion will be made with stake holders of each milk shed, woredas and kebeles. All calves up to 9 months of age were considered for this study.

\section{Study design and sampling method}

A cross-sectional study to assess calf management, calf health problems and associated risk factors was conducted. Representative small holder dairy farms were purposively sampled based on the availability of dairy cows with up to 6 months of age (weaning age) and up to 9 months (post weaning/age). The selection process of farmers was done purposely by considering the availability milking cows and calves up to 9 months.

From the two zones purposively 6 districts were selected by taking in to account the availability of potential dairy farming. Then 15 representative PAs included in the study. From Sidama zone (Hawassa, Tula, Hula, AletaWondo, Aleta Chuko) districts were purposively selected while, from Gedio zone (Dilla) district were selected. Open target group discussion was made in order to get the required data then representative farmers were interviewed and required data collected starting from October 2010 to December 2013.

\section{Observational assessment on calf management}

An observational assessment of the housing (barn floor) and hygienic practices being followed in calf sheds was performed. Housing hygiene was graded from 1 to $4 ; 1=$ very clean, $2=$ clean, $3=$ poor, $4=$ very poor. The feeds that available to the calves were evaluated according to the type of feed (colostrum, concentrate, hay or straw).

\section{Questionnaire survey}

The questionnaire was pre-tested in a selected study location and modified before the main survey. The questions also were include the age, gender and education background of the responsible personnel, farm location, farming system, calf rearing practices, feeding and housing of the animals, disease-control and prevention practices. Information on cow milk production, as well as the breed and age of calves were recorded. Gender aggregated data was generated to see the role of each family member in calf health management practice. Laboratory sample was llected for Standard microbiological, internal parasite identification.

\section{Gastrointestinal parasite}

The fecal samples were collected from calves aged up to 9 months per rectum in a sterile bottle. All the specimens were clearly identified, labeled, kept in an ice box and were submitted Woliata Sodo Regional laboratory and stored at $4{ }^{\circ} \mathrm{C}$ until it was processed. The samples were processed by Standard Flotation and Sedimentation techniques to investigate the eggs of helminth parasites. Nematode eggs were identified by floatation technique in saturated $\mathrm{NaCl}$ solution and Trematodes were examined by sedimentation methods. The eggs 
Citation: Yibrah T, Tsega B. Cross-Sectional Study on Calf Health and Management Problems on Small Scale Dairy Farms of Sidama and Gedio Zones, Southern Ethiopia. J Veter Sci Med. 2017;5(1): 5.

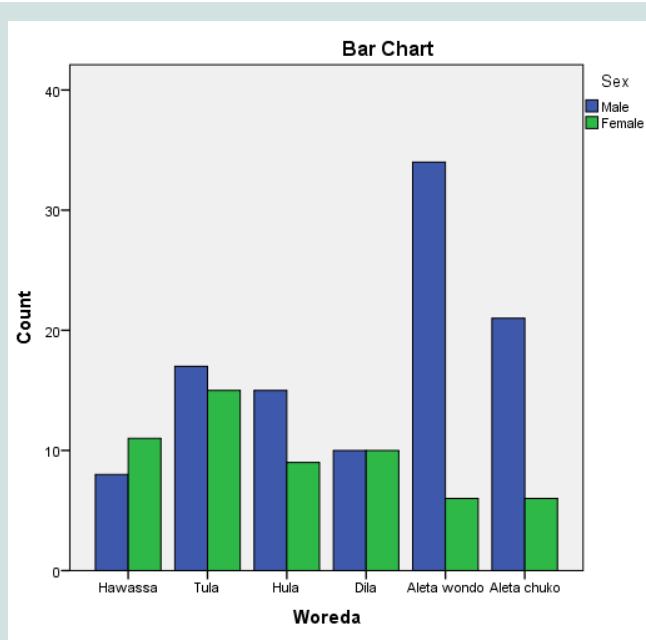

Figure 1: Gender aggregation of respondents in different districts.

Table 1: Reveals demographic data of the respondents.

\begin{tabular}{|c|c|c|c|}
\hline Variable & Categories & Frequency & Percent (\%) \\
\hline Gender & $\begin{array}{l}\text { Male } \\
\text { Female } \\
\text { Total }\end{array}$ & $\begin{array}{c}105 \\
57 \\
162\end{array}$ & $\begin{array}{l}64.8 \% \\
35.2 \% \\
100 \%\end{array}$ \\
\hline Age & $\begin{array}{c}16-30 \\
31-45 \\
46-60 \\
\text { Greater than } 60 \text { years } \\
\text { Total }\end{array}$ & $\begin{array}{c}34 \\
75 \\
36 \\
17 \\
162\end{array}$ & $\begin{array}{l}21.0 \% \\
46.3 \% \\
22.2 \% \\
10.5 \% \\
100 \%\end{array}$ \\
\hline Educational level & $\begin{array}{c}\text { Illiterate } \\
\text { primary } \\
\text { secondary } \\
\text { College/university } \\
\text { Total }\end{array}$ & $\begin{array}{c}19 \\
93 \\
48 \\
2 \\
162\end{array}$ & $\begin{array}{c}11.7 \% \\
57.4 \% \\
29.6 \% \\
1.2 \% \\
100 \%\end{array}$ \\
\hline Farming system & $\begin{array}{c}\text { Intensive } \\
\text { Semi-intensive } \\
\text { Extensive } \\
\text { Total }\end{array}$ & $\begin{array}{c}61 \\
47 \\
54 \\
162\end{array}$ & $\begin{array}{l}37.7 \% \\
29.0 \% \\
33.3 \% \\
100 \%\end{array}$ \\
\hline Farm Location & $\begin{array}{c}\text { Urban } \\
\text { Peri-urban } \\
\text { Rural } \\
\text { Total }\end{array}$ & $\begin{array}{c}47 \\
41 \\
74 \\
162\end{array}$ & $\begin{array}{l}29.0 \% \\
25.3 \% \\
45.7 \% \\
100 \%\end{array}$ \\
\hline
\end{tabular}

of Fasciola and Paramphistomum species were distinguish by their morphological characteristics and colour differences. Strongyle positive fecal samples were identified based on methods described by Soulsby, Urquhart et al., Maff and RVC/FAO [17-20].

\section{Microbiological identification}

All diarrheic calves and healthy calves were sampled from each selected farms. Faecal samples were collected directly from the rectum of the calf with rectal swabs. The samples were stored in a icebox and sent to Wolaita Sodo Regional Laboratory for examination. The sterile rectal swab samples were cultivated on culturing media and bacterial isolates were subjected to characterization to study their morphological, cultural, and biochemical characteristics as well as their motility according to Quinn et al. [21].

\section{Statistical analysis}

The collected data were analyzed using Statstical Package for Social Sciences version 20 (SPSS, 2011): frequency, percentage, description and comparisons of dairy farmers their management systems and problems. The association between risk factors versus disease prevalence was analyzed using binary logistic regression. Multivariate statistical analysis was performed using multinomial logistic regression.

\section{Results and Discussion}

\section{Description of respondents' characteristics}

When observing the respondents gender $64.8 \%$ were male which higher than female number scored $35.2 \%$. The minimum age was 16 years old and the maximum age is 90 ; the overall mean was 42 years (Table 1).

The highest numbers of female respondent are selected from Sidama zone which accounts about $29.0 \%$ of the total female participant and Gedio zone has $6.2 \%$ females from the total population (Table 2).

When respondents gender aggregation in selected districts of Sidama and Gedio zone (Figure 1), higher proportion 9.3\% from Tula sub city followed by $6.8 \%$ of female from Hawassa, $6.2 \%$ from
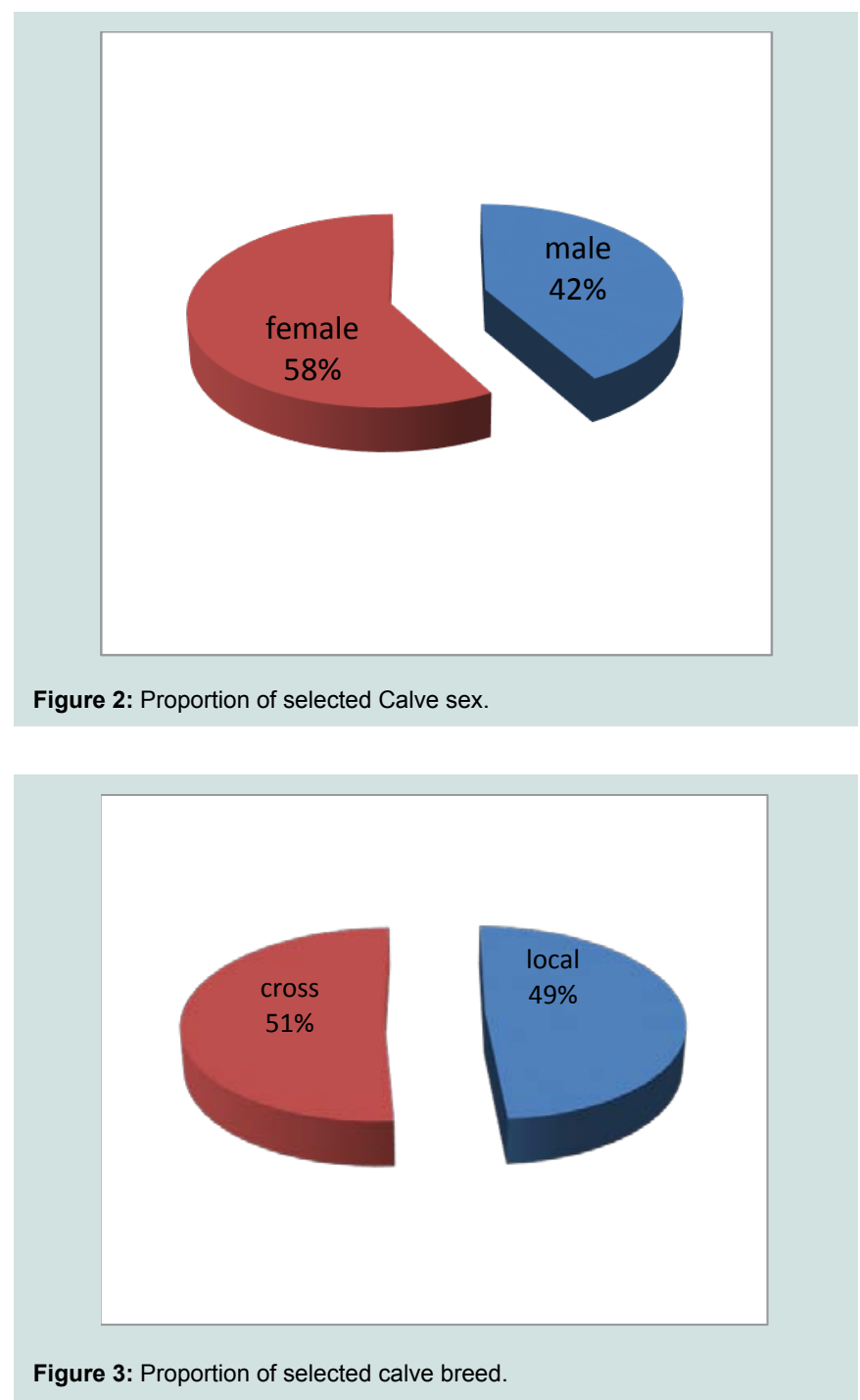
Citation: Yibrah T, Tsega B. Cross-Sectional Study on Calf Health and Management Problems on Small Scale Dairy Farms of Sidama and Gedio Zones, Southern Ethiopia. J Veter Sci Med. 2017;5(1): 5.

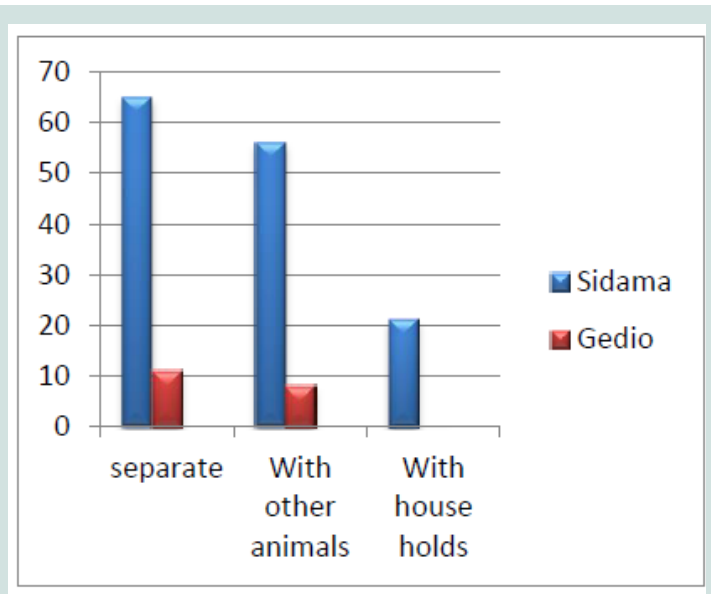

Figure 4: Separate housing condition

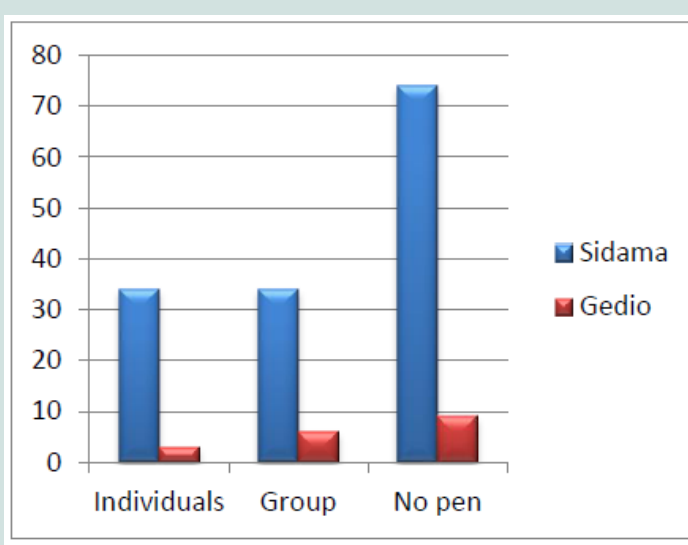

Figure 5: Calf housing condition.

Dilla, 6.0\% from Aleta wondo, 5.6\% from Hula and the least 3.7\% from Aleta chuko districts.

\section{Livestock rearing practice}

Majority of the Livestock owners keep more local breed cattle than cross breed. The mean average value of local breed cow is 2.07 $(\mathrm{R}=0-12, \mathrm{SD}=2.320)$ and for cross breed cow $1.19(\mathrm{R}=0-11, \mathrm{SD}=$ 1.601). The average livestock size is $6.71(\mathrm{R}=0-23, \mathrm{SD}=4.264)$ (Table 3).

\section{Breed and sex}

A total of 86 calves were selected and examined for present and previous disease history and the management practice they were kept in. From the above figure $42(48.84 \%)$ calves were local breeds and 44 (51.16\%) were cross breed calves (Figures 2 and 3 ).

\section{General housing condition, hygiene and feed sources}

Respondents house arrangement was in $76 \%$ calves housed separately, $64 \%$ housed with others and $21 \%$ housed with households. In separated house $39 \%$ penned individually, $40 \%$ housed in group and $83 \%$ had no pen (Figures 4 and 5).

\section{Delivery condition}

Birth condition history of selected calves $(\mathrm{N}=86)$ was taken from the owners; apparently 14 (16.28\%) calves were born from cows with difficulty in delivery. The prevalence of difficulty in birth was higher in Sidama zone 13 (15.11\%) than Gedio zone 1 (1.16\%).

Home delivery, $14(16.12 \%)$, is the most problem in both study zones which attended by the owners who have not information about veterinary profession whereas bout $1(1.16 \%)$ was assisted by veterinarians; but the remains $83.72 \%$ delivery condition was normal without any delivery assistance. This finding agreed with the finding of Odoch who reported non-assisted delivery of $82 \%$ whereas the assisted and normal delivery condition of this study was lower than the findings of found in and around Mekelle 5 (2.36\%) and 207 (97.64\%) respectively [22]. Respondent's observation at the time of delivery conditions indicated as $6(50.00 \%)$ of the problems brought from both calf and maternal caused difficulties and 4 (28.57\%) was the oversized calf cause (Table 4).

\section{Colostrum feeding habit}

Majority of Dairy farms owners and/or attendants, 150 (92.59\%),

Table 2: Gender distribution among different zones and farm location.

\begin{tabular}{|c|c|c|c|c|c|}
\hline \multirow{2}{*}{ Zone } & Gender & \multicolumn{3}{|c|}{ F arm location } & Total N (\%) \\
\hline & & Urban & Peri-urban & Rural & \\
\hline \multirow{2}{*}{$\begin{array}{c}\text { Sidama } \\
(\mathrm{N}=142)\end{array}$} & Male & $26(18.3 \%)$ & $33(23.2 \%)$ & $36(25.4 \%)$ & $95(58.6 \%)$ \\
\cline { 2 - 6 } & Female & $28(19.7 \%)$ & $8(5.6 \%)$ & $11(7.7 \%)$ & $47(29.0 \%)$ \\
\cline { 2 - 6 } & Total & $54(33.3 \%)$ & $41(25.3 \%)$ & $47(29.0 \%)$ & $142(87.6 \%)$ \\
\hline \multirow{2}{*}{ Gedio } & Male & $5(25.0 \%)$ & $3(15.0 \%)$ & $2(10.0 \%)$ & $10(6.2 \%)$ \\
\cline { 2 - 6 }$(\mathrm{N}=20)$ & Female & $2(10.0 \%)$ & $3(15.0 \%)$ & $5(25.0 \%)$ & $10(6.2 \%)$ \\
\cline { 2 - 6 } & Total & $7(4.3 \%)$ & $6(3.7 \%)$ & $7(4.3 \%)$ & $20(12.4 \%)$ \\
\hline \multirow{2}{*}{ Total } & Male & $31(19.1)$ & $35(21.6 \%)$ & $38(23.4 \%)$ & $105(64.8 \%)$ \\
$(\mathrm{N}=162)$ & Female & $30(18.5 \%)$ & $11(6.7 \%)$ & $16(9.8 \%)$ & $57(35.2 \%)$ \\
& Total & $61(37.6 \%)$ & $46(28.4 \%)$ & $54(33.3 \%)$ & $162(100 \%)$ \\
\hline
\end{tabular}

Table 3: Statistical distribution of the selected dairy farms herd.

\begin{tabular}{|c|c|c|c|c|c|c|c|}
\hline Cattle Type & $\mathbf{N}$ & Sum & Range & Minimum & Maximum & Mean & $\begin{array}{c}\text { Std. } \\
\text { Deviation }\end{array}$ \\
\hline Local cows & 162 & 336 & 12 & 0 & 12 & 2.07 & 2.320 \\
\hline Cross cows & 162 & 193 & 11 & 0 & 11 & 1.19 & 1.601 \\
\hline Total Cows & 162 & 529 & 15 & 0 & 15 & 3.23 & 2.434 \\
\hline Local oxen & 162 & 55 & 3 & 0 & 3 & 0.34 & 0.580 \\
\hline Cross oxen & 162 & 8 & 6 & 0 & 6 & 0.05 & 0.580 \\
\hline Total oxen & 162 & 63 & 6 & 0 & 6 & 0.40 & 0.743 \\
\hline Local bull & 162 & 35 & 2 & 0 & 2 & 0.21 & 0.427 \\
\hline cross bulls & 162 & 6 & 1 & 0 & 1 & 0.04 & 0.189 \\
\hline Total bulls & 162 & 41 & 3 & 0 & 3 & 0.26 & 0.495 \\
\hline Local heifer & 162 & 75 & 4 & 0 & 4 & 0.46 & 0.842 \\
\hline cross heifers & 162 & 50 & 5 & 0 & 5 & 0.31 & 0.671 \\
\hline Total heifers & 162 & 125 & 5 & 0 & 5 & 0.78 & 1.001 \\
\hline $\begin{array}{l}\text { Total local } \\
\text { calves }\end{array}$ & 162 & 199 & 6 & 0 & 6 & 1.22 & 1.329 \\
\hline $\begin{array}{l}\text { Total cross } \\
\text { calves }\end{array}$ & 162 & 135 & 7 & 0 & 7 & 0.83 & 1.201 \\
\hline $\begin{array}{l}\text { Total no. of } \\
\text { calves }\end{array}$ & 162 & 334 & 9 & 0 & 9 & 2.06 & 1.430 \\
\hline $\begin{array}{l}\text { Total cattle } \\
\text { herd }\end{array}$ & 162 & 1087 & 23 & 0 & 23 & 6.71 & 4.264 \\
\hline
\end{tabular}


Citation: Yibrah T, Tsega B. Cross-Sectional Study on Calf Health and Management Problems on Small Scale Dairy Farms of Sidama and Gedio Zones, Southern Ethiopia. J Veter Sci Med. 2017;5(1): 5.

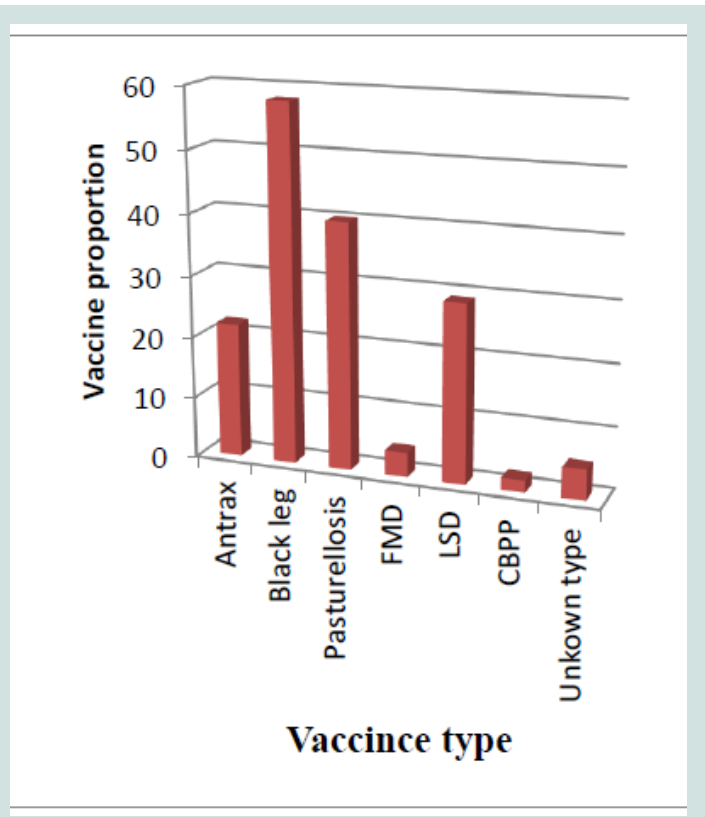

Figure 6: Vaccination practice of respondents.

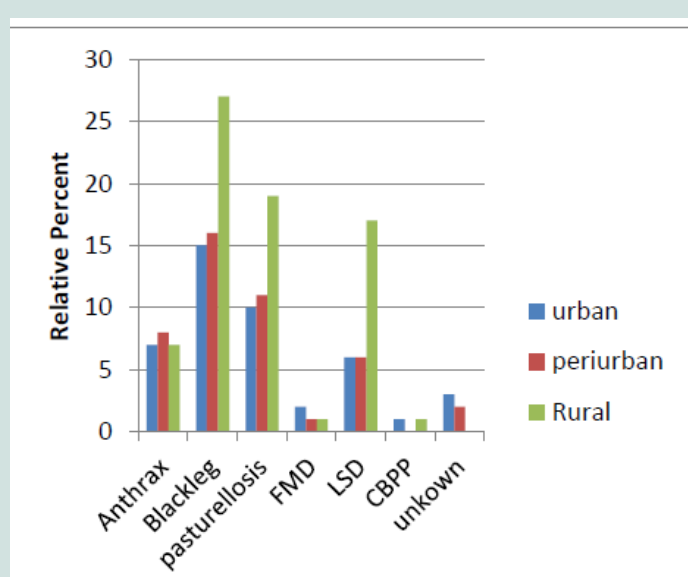

\section{Vaccine type in different dairy farm location}

Figure 7: Vaccination practice in different farm location.

were practiced colostrum feeding to their new born calves whereas about $12(7.40 \%)$ were not practiced. This shows most of the farmers have acknowledge the importance of colostrum feeding. Disease prevalence in calves which had colostrum is less affected by the disease than calves which didn't consume any. According to the respondents the suckling colostrum feeding system, 134 (82.71) was the dominant one in the dairy farms and this followed by manual feeding system, 23 (14.2\%). Most of the farmers feed their calf twice a day, $73(45.06 \%)$ and followed by three times a day $62(38.27 \%)$, Free access 9 (5.56\%), once a day 4 (2.47\%) and no colostrum feeding $2(1.23 \%)$. The majority the farmers fed their calf immediately after birth from 1-6 hours were 119 (73.45\%) followed by greater than 24 hours, $26(16.04 \%)$ and from 6-24 hours, 12 (7.4\%). Most of dairy farm owners fed their calves twice daily 73 (45.06\%) followed by 62 (38.27\%) and 2 (1.23\%) (Table 5).

\section{Calf morbidity}

There is no significant difference the calves' morbidity between selected Zone's farms ( $p>0.05)$. The survey shows $30.2 \%$ an overall calf morbidity in the study area farms, of a total of 48 calves were found ill from the all selected calves $(\mathrm{N}=159)$. High Prevalence of calf morbidity was observed in urban area farms, $12.6 \%$ and followed by rural area farms (9.4\%) and peri-urban area farms $8.2 \%$. In general, the disease prevalence in Zones stated that high disease occurrence of calves' morbidity observed in Gedio zone, $35.0 \%$ and followed by Sidama zone, 29.3\% (Table 6).

The current Regional prevalence $30.2 \%(\mathrm{~N}=159)$ was comparable with 29.3\% $(\mathrm{N}=140)$ study of Bekele et al. in selected dairy farms of Hawassa, in the same region [23]. The present finding was somewhat lower than from the reports, Jelly et al. who reported a prevalence of morbidity $58.4 \%$ in Tanizania, Konjit et al. revealed that the affected calf was $54.1 \%$ in and around Mekelle, Ibrahm and Lemma indicated 52.3\% morbidity due to various disease in market oriented dairy farms $[9,12,24]$. This difference might be due to improper calf management, different agro ecological and climatic of the study areas.

\section{General disorders in calves}

Based on clinical signs and symptoms it was noticed that the most frequently observed disease cases were due to bacterial infections (Septicemia and Diarrhea) (43.7\%), internal parasites (31.2\%), external parasites (16.7\%), mixed infections (4.2\%) and hemoparasite $(2.08 \%)$ and coccidiosis (2.08\%).

In this study, the septicemic and diarrheic (43.7\%) and Internal parasite $(31.2 \%)$ cases found in the study area. The farmers were aware of these two disorders in their calves and rated as most common. Lema et al., Wudu et al. and Jelly reported similar results $[8,9,16]$. The Poor hygienic conditions in the calf barns and inappropriate use of anthelmintics observed during the study might be responsible for the high occurrence of these conditions (Table 7).

Table 4: Indicates the problem of delivery condition in the selected study area.

\begin{tabular}{|l|c|c|c|c|}
\hline \multirow{2}{*}{ Causes } & \multicolumn{3}{c|}{ Farm Location } & \multirow{2}{*}{ Total } \\
\cline { 2 - 5 } & Urban & Peri-urban & Rural & \\
\hline Major problems & & & & \\
\hline Calf caused & $0(0.00 \%)$ & $1(7.14 \%)$ & $0(0.00 \%)$ & $1(7.14 \%)$ \\
\hline Maternal caused & $0(0.00 \%)$ & $0(0.00 \%)$ & $1(7.14 \%)$ & $1(7.14 \%)$ \\
\hline Both & $6(42.85 \%)$ & $0(0.00 \%)$ & $1(7.14 \%)$ & $7(50 \%)$ \\
\hline No knowhow & $0(0.00 \%)$ & $3(21.42 \%)$ & $2(14.28 \%)$ & $5(35.71 \%)$ \\
\hline Calve caused problems & & & & \\
\hline Over sized & $3(21.42 \%)$ & $0(0.00 \%)$ & $1(7.14 \%)$ & $4(28.57 \%)$ \\
\hline Hydrocephalic & $0(0.00 \%)$ & $1(7.14 \%)$ & $0(0.00 \%)$ & $1(7.14 \%)$ \\
\hline No knowhow & $0(0.00 \%)$ & $1(7.14 \%)$ & $2(14.28 \%)$ & $3(21.42 \%)$ \\
\hline Total & $3(21.42 \%)$ & $2(14.28 \%)$ & $3(21.42 \%)$ & $8(57.14 \%)$ \\
\hline Maternal caused & & & & \\
\hline problems & & & & \\
\hline Narrow Pelvic bone & $1(6.7 \%)$ & $0(0.0 \%)$ & $1(6.7 \%)$ & $2(14.28 \%)$ \\
\hline Impotency & $2(13.3 \%)$ & $0(0.0 \%)$ & $0(0.0 \%)$ & $2(14.28 \%)$ \\
\hline No knowhow & $0(0.00 \%)$ & $2(14.28 \%)$ & $0(0.00 \%)$ & $2(14.28 \%)$ \\
\hline \multicolumn{1}{|c|}{ Total } & $\mathbf{3 ( 2 1 . 4 2 \% )}$ & $\mathbf{2 ( 1 4 . 2 8 \% )}$ & $\mathbf{1 ( 7 . 1 4 \% )}$ & $\mathbf{6 ( 4 2 . 8 5 \% )}$ \\
\hline
\end{tabular}


Citation: Yibrah T, Tsega B. Cross-Sectional Study on Calf Health and Management Problems on Small Scale Dairy Farms of Sidama and Gedio Zones, Southern Ethiopia. J Veter Sci Med. 2017;5(1): 5.

ISSN: $2325-4645$

Table 5: Colostrum feeding practices of the dairy farms.

\begin{tabular}{|c|c|c|c|}
\hline \multirow{2}{*}{\begin{tabular}{|l|l} 
& Different variables \\
Colostrum feeder &
\end{tabular}} & \multicolumn{2}{|c|}{ Selected zones } & \multirow[t]{2}{*}{ Tota } \\
\hline & Sidama & Gedio & \\
\hline Yes & $130(80.2 \%)$ & $20(12.3 \%)$ & $150(92.59 \%)$ \\
\hline No & $12(7.4 \%)$ & $0(0.0 \%)$ & $12(7.40 \%)$ \\
\hline \multicolumn{4}{|l|}{ Colostrum feeding system } \\
\hline Suckling & $115(72.8 \%)$ & $19(12.0 \%)$ & $134(82.71)$ \\
\hline Manual feeding & $22(13.9 \%)$ & $1(0.6 \%)$ & $23(14.2 \%)$ \\
\hline No idea & $3(1.8 \%)$ & $2(1.23 \%)$ & $5(3.08 \%)$ \\
\hline \multicolumn{4}{|l|}{ Amount of colostrum } \\
\hline Less than on litter & $40(25.5 \%)$ & $13(8.3 \%)$ & $53(32.71 \%)$ \\
\hline 1-2 liter & $54(33.3 \%)$ & $6(3.7 \%)$ & $60(37.03 \%)$ \\
\hline \multicolumn{4}{|l|}{ Feeding time } \\
\hline $1-6 \mathrm{hrs}$ & $109(69.0 \%)$ & $10(6.3 \%)$ & $119(73.45 \%)$ \\
\hline With 6- 24 hrs & $11(7.0 \%)$ & $1(0.6 \%)$ & $12(7.4 \%)$ \\
\hline Greater than $24 \mathrm{hrs}$ & $17(10.8 \%)$ & $9(5.7 \%)$ & $26(16.04 \%)$ \\
\hline No idea & $5(3.09 \% \%)$ & $0(0.0 \%)$ & $5(3.09 \%)$ \\
\hline \multicolumn{4}{|l|}{ Frequency of feeding colostrum in a day } \\
\hline Once a day & $2(1.3 \%)$ & $2(1.3 \%)$ & $4(2.47 \%)$ \\
\hline Twice a day & $64(41.3 \%)$ & $9(14.0 \%)$ & $73(45.06 \%)$ \\
\hline Three times a day & $58(37.4 \%)$ & $4(2.6 \%)$ & $62(38.27 \%)$ \\
\hline Free access & $9(5.8 \%)$ & $0(0.0 \%)$ & $9(5.56 \%)$ \\
\hline No colostrum feeding & $2(1.3 \%)$ & $0(0.0 \%)$ & $2(1.23 \%)$ \\
\hline
\end{tabular}

Table 6: Indicates the calf morbidity on selected Zones.

\begin{tabular}{|c|c|c|c|}
\hline Zones & Urban (N) & Peri-urban (N) & Rural (N) \\
\hline Sidama & $(12.2 \%) 17$ & $(8.6 \%) 12$ & $(8.6 \%) 12$ \\
\hline Gedio & $(15.0 \%) 3$ & $(5.0 \%) 1$ & $(15.0 \%) 3$ \\
\hline Total & $(\mathbf{1 2 . 6 \% )} \mathbf{2 0}$ & $\mathbf{( 8 . 2 \% )} \mathbf{1 3}$ & $\mathbf{( 3 5 . 0 \% )} 7$ \\
\hline
\end{tabular}

\section{Bacteria isolation}

From the respondents' response the major calf problems were neonatal diarrhea, septicemia and helmenthosis, the intensity of calf's diarrhea due to both bacterial infection and internal parasites were analised. E.coli (53.3\%) was found to be the higher prevalent bacteria and followed by Proteus (10\%), Citrobacter (8.3\%), E.coli \& Klebsiella mixed $(8.3 \%)$ and the remaining bacteria were with lower prevalence (Table 8).

\section{Helminthes identification}

The major internal parasites identified by the floatation and sedimentation were Strongyle spp. (32\%), emeria (16\%), Neoasacris vitulorum (12.0\%), mixed parasite Strongyle spp. and Eimeria (10\%) and Neoascaris vitulorum and Strongyle spp. (8\%) (Table 9). The overall prevalence of Eimeria species infection (16\%) in this study is lower than Kassa et al. found (24.9\%) Eimeria infections in Tana based on a retrospective laboratory study. This suggests that Eimeria infections are more prevalent in varied agroecology of Ethiopian dairy farms.
The results indicate the unhygienic conditions in farm, lack of clean water and poor management practices adopted by the farmers.

\section{Vaccination practices}

The result indicates that $82(50.9 \%)$ calves received vaccination at least for one vaccine type. according to the respondent response and about 58 (35.3\%) vaccination practiced with Blackleg vaccine followed by 40 (24.7\%) Pasturella, 29 (17.9\%) Lumpy skin disease, $22(13.6 \%)$ anthrax vaccines were practiced (Figure 6). The majority farmer's calves expose to vaccination for the above listed diseases; this might be due to the higher occurrence and devastating effect of the diseases. Many researchers reported the distribution of Blackleg and Anthrax diseases were as the most frequently observed diseases $[25,26]$. On the other hand, vaccine for contagious Bovine Pleuro pneumonia (CBPP) was rarely used. Except blackleg vaccine practice (58\%) the rest were lower than half of the total farmers vaccinated their calves for each vaccine type; Pasturellosis (40\%), Foot and mouth disease (29\%), Lumpy skin disease (29\%), anthrax (22\%) and CBPP (2\%) (Figures 6 and 7). 
Citation: Yibrah T, Tsega B. Cross-Sectional Study on Calf Health and Management Problems on Small Scale Dairy Farms of Sidama and Gedio Zones, Southern Ethiopia. J Veter Sci Med. 2017;5(1): 5.

ISSN: $2325-4645$

Table 7: The major calf diseases observed in selected dairy farms.

\begin{tabular}{|c|c|c|c|}
\hline No. & Case identified & Affected calves & Cumulative Percent \\
\hline 1 & Hemoparasite & 1 & $2.08 \%$ \\
\hline 2 & External parasites & 8 & $16.7 \%$ \\
\hline 3 & Internal parasites & 15 & $31.2 \%$ \\
\hline 4 & Sepcicemia and Diarrhea & 21 & $43.7 \%$ \\
\hline 5 & Mixed infection & 2 & $4.2 \%$ \\
\hline 6 & Coccidiosis & 1 & $2.08 \%$ \\
\hline & Total & $\mathbf{4 8}$ & $100 \%$ \\
\hline
\end{tabular}

Table 8: shows the bacteria isolated from the selected calves in the study area

\begin{tabular}{|l|c|c|}
\hline Isolated bacteria & Frequency & Percent (\%) \\
\hline E.Coli & 32 & 53.3 \\
\hline Klebsiella & 3 & 5.0 \\
\hline Entro-Bacter & 1 & 1.7 \\
\hline Citero-Bacter & 5 & 8.3 \\
\hline Proteus & 6 & 10.0 \\
\hline Proteus \& Salmonella & 1 & 1.7 \\
\hline E.Coli \& Kelipsella & 5 & 8.3 \\
\hline Citro-Bacter \& Entro-Bactor & 1 & 1.7 \\
\hline Proteus\&Klebsiella & 2 & 3.3 \\
\hline Entrobacter \& Proteus & 1 & 1.7 \\
\hline Entro bacter \& E.Coli & 1 & 1.7 \\
\hline Proteus \& E.Coli & 1 & 1.7 \\
\hline E.coli and Salmonella & 1 & 1.7 \\
\hline Total & $\mathbf{6 0}$ & 100 \\
\hline
\end{tabular}

Table 9: indicates the identified internal parasites in the selected study area.

\begin{tabular}{|l|c|c|}
\hline \multicolumn{1}{|c|}{ Identified Parasite } & Frequency & Percent (\%) \\
\hline Strongyle spp. & 16 & 32.0 \\
\hline Eimeria & 8 & 16.0 \\
\hline Neoascaris vitulorum & 6 & 12.0 \\
\hline Faciola & 2 & 4.0 \\
\hline Strongyloides & 1 & 2.0 \\
\hline Strongyle spp. + Eimeria & 5 & 10.0 \\
\hline Neoascaris vitulorum + Faciola & 1 & 2.0 \\
\hline Strongyle spp. + Faciola & 1 & 2.0 \\
\hline Neoascaris vitulorum + Strongyle spp. & 4 & 8.0 \\
\hline Strongyle spp. + Strongyloides & 3 & 6.0 \\
\hline Strongyloides + Strongyle spp. + Eimeria & 2 & 4.0 \\
\hline $\begin{array}{l}\text { Strongyle spp. + Eimeria + Neoascaris } \\
\text { vitulorum }\end{array}$ & 1 & 2.0 \\
\hline Total & $\mathbf{5 0}$ & 100.0 \\
\hline
\end{tabular}

\section{Conclusion and Recommendations}

The health and management of calves are credential component of total dairy productivity. Time at the first colostrum feeding, housing condition, clean water, delivery system, and vaccination programs are major factors that affect health of calf. The present study also showed that bacteria related diarrhea was dominant calf health problem and followed internal parasite and external parasite and other infection. This problem can be minimized by improving dam and calve health through different management system and applying routine vaccination procedure.

Though the cause of these diseases are diverse in their nature, poor management practices (feeding, housing, hygiene) and poor health care practice takes the largest portion of the pie. Farmers have to follow good colostrums feeding management satisfying the quality, quantity and time of colostrum feeding. Therefore, these devastating calf heath condition need to be solved by further research findings and supportive animal health extension programs targeting the following aspects of management interventions:

- Vaccination programs should be designed to protect against diseases that occur commonly in the district, plus any specific disease occurring on individual farms. The timing of the vaccination and the selection of the product are important considerations

- Housing to minimize transfer of disease between calves, such as using individual pens and good hygiene of calf pens and feeding equipment and Close attention to animal health to minimize the incidence of calf scours, pneumonia and other diseases.

- Appropriate feeding management based on formulating palatable calf concentrates to supply adequate energy, protein and fiber.

- Ensure easy access to veterinarians and other animal health specialists to develop and implement effective animal health programs

\section{References}

1. Tegegne A, Gebrewold A (1998) Prospects for periurban dairy development in Ethiopia proceeding of 5 th conference of Ethiopian society of animal Production (ESAP), 15-17 May 1997, Addis Ababa Ethiopia, pp. 28-39.

2. Rodostitis OM, Blood DC, Gay CC (1994) Veterinary Medicine. A text book of the diseases of cattle, sheep, pigs, goats and horses, $\left(8^{\text {th }} e d n\right)$. Bailliere Tindal.

3. ILCA (International Livestock Center for Africa) (1994) ILCA Annual Program Report 1993/1994. Addis Ababa, pp. 73-74.

4. Eneyew N, Branng E, Rottoman OJ (2000) Reproductive performance and herd life of cross bred dairy cattle with different level of European inheritance in Ethiopia. Proceeding of 7th conference of Ethiopian Society of Animal Production (ESAP), Addis Ababa, Ethiopia, pp. 157-162.

5. Goshu G, Singh H (2013) Lactation specific and life time demographic parameters in a Holstein Friesian herd in the central highlands of Ethiopia. Livestock Research for Rural Development 25.

6. Eshetu GR (2014) Major causes of calf mortality in intensive dairy farms, Central Ethiopia: A cohort study. Int J Livest Res 4: 9-16.

7. Gitau GK, Mc Dermott JJ, Waltner-Toews D, Lissemore KD, Osumo JM, et al. (1994) Factors influencing calf morbidity and mortality in smallholder dairy farms in Kiambu District of Kenya. Prev Vet Med 21: 167-177.

8. Wudu T, Kelay B, Mekonnen HM, Tesfu K (2008) Calf morbidity and mortality in smallholder dairy farms in Ada'a Liben district of Oromia, Ethiopia. Trop Anim Health Prod 40: 369-376.

9. Chang'a JS, Mdegela RH, Ryoba R, Løken T, Reksen O (2010) Calf health and management in smallholder dairy farms in Tanzania. Trop Anim Health Prod 42: 1669-1676.

10. Stoltenow CL, Vincent LL (2003) Calf scours: Causes, prevention, Treatment. 
Citation: Yibrah T, Tsega B. Cross-Sectional Study on Calf Health and Management Problems on Small Scale Dairy Farms of Sidama and Gedio Zones, Southern Ethiopia. J Veter Sci Med. 2017;5(1): 5.

ISSN: $2325-4645$

NDSU Extension Service, North Dakota State University, Fargo, North Dakota.

11. Darsema G (2008) Major causes of calf mortality in dairy farm and two cattle ranches in western region, North Western Ethiopia. Ethiop Vet J 12: 59-68.

12. Mengesha K, Gurmu EB, Hussein D (2013) Major management and health problems of calves in dairy farms in and around Mekelle. REDVET Rev Electrón Vet: 14

13. Keyyu JD, Kyvsgaard NC, Monrad J, Kassuku AA (2005) Epidemiology of gastrointestinal nematodes in cattle on traditional, small-scale dairy and large-scale dairy farms in Iringa district, Tanzania. Vet Parasitol 127: 285294.

14. Keyyu JD, Kassuku AA, Msalilwa LP, Monrad J, Kyvsgaard NC (2006) Crosssectional prevalence of helminth infections in cattle on traditional, small-scale and large-scale dairy farms in Iringa district, Tanzania. Vet Res Commun 30: 45-55.

15. Keyyu JD, Kyvsgaard NC, Monrad J, Kassuku AA (2009) Effectiveness of strategic anthelmintic treatments in the control of gastrointestinal nematodes and Fasciola gigantica in cattle in Iringa region, Tanzania. Trop Anim Health Prod 41: 25-33.

16. Lema M, Kassa T, Tegegne A (2001) Clinically manifested major health problems of crossbred dairy herds in urban and periurban production systems in the central highlands of Ethiopia. Trop Anim Health Prod 33: 85-93.
17. Soulsby EJ (1982) Helminths, Atropods and Protozoa of domesticated animals, $\left(7^{\text {th }}\right.$ edn). Lea and Febiger, Philadelphia, pp. 37-50.

18. Urquhart GM, Aremour J, Duncan JL, Dunn AM, Jeninings FW (1996) Veterinary parasitology, $\left(2^{\text {nd }} e d n\right)$. Wiley-Blackwell, pp. 3-137.

19. MAFF (1971) Manual of veterinary parasitological laboratory techniques. Technical Bulletin, London No. 18.

20. Gibbons LM, Jacobs DE, Fox MT (2009) The RVC/FAO Guide to veterinary diagnostic parasitology: Faecal examination of farm animals for helminth parasites.

21. Quinn PJ, Markey BK, Leonard FC, FitzPatrick ES, Fanning S, et al. (2011) Veterinary microbiology and microbial diseases, ( $\left.2^{\text {nd }} e d n\right)$. Wiley-Blackwell, UK, pp. 84-96

22. Amoki OT (2001) Management of dairy calves in Holleta area, central highlands of Ethiopia. Msc. Thesis, Faculty of Veterinary Medicine, Addis Ababa University, Debre Zeit, Ethiopia.

23. Megersa B, Yacob A, Regassa A, Abunna F, Asmare K, et al. (2009) Prevalence and incidence rates of calf morbidity and mortality and associated risk factors in smallholder dairy farms in Hawassa, Southern Ethiopia. Ethiop Vet J 13: 59-68.

24. Ibrahm A, Lemma A (2009) Relationships between serum protein concentration and passive transfer of immunity, morbidity and mortality of dairy calves in market oriented urban dairy farms. Revue Méd Vét 8-9: 394399. 